\title{
A.JO'ГE
}

African Journal of Teacher Education

ISSN 1916-7822. A Journal of Spread Corporation

Volume 9. No.2 2020 Pages $110-143$

\section{A Typology of Professional Learning Communities (PLC) for Sub-Saharan Africa: A Case study of Equatorial Guinea, Ghana, and Nigeria}

\author{
Dr. Fernanda Soares, Kirsten Galisson ${ }^{1}$ \\ Family Health International 360 (FHI 360), 1875 Connecticut Avenue NW, \\ Washington, DC 20009, USA \\ \& \\ Dr. Mindel van de Laar $^{1}$ \\ Maastricht Graduate School of Governance / United Nations University - MERIT, \\ Maastricht University, Boschstraat 24, 6211 AX Maastricht, The Netherlands
}

\begin{abstract}
In the bid to improve teaching quality and promote an approach to teacher development that is grounded in the context in which teachers are inserted, Professional Learning Communities (PLCs) have become a popular alternative model of teacher professional development in many countries. PLCs, however, have been more widely studied in high-resource contexts. In a recognition that existing conceptualizations from the Western literature may not reflect how PLCs are functioning in developing countries, this research aims to inductively create a typology of PLCs that incorporates elements that might be specific to these countries, with a focus on Sub-Saharan Africa in general and based on the cases of Equatorial Guinea, Ghana and Nigeria in particular. This study employs a multimethod approach, encompassing document analysis, semi-structured interviews with PLC experts and expert validation. The resulting typology categorizes PLCs into three models; autonomous, structured and scripted.
\end{abstract}

\footnotetext{
${ }^{1}$ F. Soares: Family Health International 360 (FHI 360), 1825 Connecticut Avenue NW, Washington, DC 20009, USA; (e-mail: fsoares@ fhi360.org)(telephone: +1.202.629.6415); K. Galisson: Family Health International 360 (FHI 360), 1825 Connecticut Avenue NW, Washington, DC 20009, USA (e-mail: kgalisson@ fhi360.org) (+1.202.884.8990); \& M. Laar, van de: (e-mail: mindel.vandelaar@maastrichtuniversity.nl, https://www.merit.unu.edu/about-us/profile/?staff_id=1332) (telephone +31-43-3884660).
} 
A Typology of Professional Learning Communities (PLC) for Sub-Saharan Africa: A Case study of Equatorial Guinea, Ghana, and Nigeria

This typology of PLCs is further integrated with dimensions previously proposed by the Western literature to form one cohesive conceptual framework. By acknowledging PLC variability, we are able to incorporate into a framework modes of PLC operation that are specific to our case countries, and possibly to Sub-Saharan African and low-and middle-income countries more generally.

Keywords: Professional Learning Communities, Teacher Professional Development, Sub-

Saharan Africa

\section{Section I: Introduction}

In efforts to improve teaching quality and promote an approach to teacher development that is both social and contextual (Du Plessis \& Muzaffar, 2010), many countries have recently started to implement alternative models of teacher professional development, such as Professional Learning Communities (PLCs). PLCs move professional development beyond the acquisition of new knowledge and skills (Vescio, Ross \& Adams, 2007) to improvement of classroom practice through collaboration among teachers (DuFour, 2004). PLCs emphasize collaboration and reflection among a group of teachers, as a way to expose them to new ideas and practices so they can improve on their pedagogy through a process of critical inquiry. PLCs have become a "hot topic" in many developing countries as they hold considerable promise for teachers' capacity building for sustainable improvement in education quality (Stoll et al., 2006). Nonetheless, the literature on PLCs has typically focused on the experience of teachers in Western countries (Toole and Louis, 2002) and PLCs in developing countries have received limited attention. While recent research on PLCs in particular in South Africa is growing (Brodie, 2019; Feldman, 2020; Ndlovu, 2018, Mhakure, 2019) mainly contributions remain theoretical in nature, and largely absent for the rest of Africa.

PLCs in developing countries may operate in different ways reflecting their unique context, society and culture. PLCs in developed countries, for example, emphasize teachers' autonomy and authority in making decisions regarding the processes, agenda and objective of their learning communities. Previous research, however, has indicated that developing countries trying to improve low-functioning education systems should focus on introducing highly specific 
approaches to instructional change (Piper et al., 2018). So, while teachers' autonomy is a key element of PLCs in developed countries, developing countries may adopt more prescriptive approaches to promoting effective instructional change, to ensure PLCs are not reinforcing and maintaining existing traditional substandard practice rather than changing it (Stoll et al., 2006).

Recognizing that existing conceptualizations from the Western literature do not reflect how PLCs function in developing countries, this research creates a typology of PLCs that incorporates elements specific to these countries, using case studies of Equatorial Guinea, Nigeria and Ghana. First, we conducted a review of existing PLC conceptualizations available in the Western literature analyzing their points of convergence, divergence, limitations and gaps. Subsequently, through a qualitative approach consisting of document analysis that covers all sub-Saharan African countries and semi-structured interviews with practitioners from our case study countries we obtained an indepth understanding of how PLCs are designed and implemented in Sub-Saharan African countries. We then integrated a typology of PLCs that emerged from our qualitative research in Sub-Saharan Africa countries with dimensions previously proposed by Western literature into one cohesive conceptual framework. To validate and refine this framework, we held discussions with practitioners involved in education programs with a PLC component from the three case study countries. ${ }^{2}$ The final framework can guide policy-makers and practitioners in the design and promotion of collaborative structures by accounting for elements specific to developing countries, and to Sub-Saharan African countries in particular.

\section{Section II: Review of PLC Conceptualizations}

Research on PLCs is still in early stages of theory building (Sleegers et al., 2013) and there is no broad consensus in the literature on a definition of PLC (Lomos, 2011; Vescio, Ross, \& Adams, 2007; Stoll et al., 2006). However, most definitions agree that PLCs involve a group of teachers sharing and critically interrogating their practice in an ongoing, reflective, collaborative, inclusive, learning-oriented, growth-promoting way (Stoll and Louis, 2007; Stoll et al., 2006; Toole and Louis, 2002; Mitchell and Sackney, 2000;). It is assumed with PLCs that knowledge is situated in the daily experiences of teachers and is best understood through critical reflection with others who share the same experience (Vescio, Ross \& Adams, 2007; Buysse et al., 2003). The literature

\footnotetext{
${ }^{2}$ The practitioners were selected based on their knowledge of PLCs in one of the case study countries, but their expertise also includes implementation of PLCs in other countries in Sub-Saharan Africa and in other continents.
} 
debates whether PLCs emerge organically in schools with effective principal and teacher leadership or if there is a place for top-down initiatives to create PLCs (Kruse \& Louis, 2007). Hence, it is still an open question whether effective PLCs necessarily result from spontaneous teacher action or can as well be produced by reforms or education programs proposed by local or national education authorities. The Hargreaves and Fullan (1992) earlier warned that collaboration is better when it is not contrived. Once PLCs are functional, however, one key point the literature emphasizes is teachers' empowerment and authority to make decisions regarding both the content and processes of their PLCs (Vescio et al., 2008; Huffman \& Jacobson, 2003; Supovitz, 2002; Englert and Tarrant, 1995). It is also assumedin the literature that PLCs will occur mainly within the school as the primary unit of effective change (Kruse \& Louis, 2007).

There are several PLC conceptualizations, with similarities as well as points of divergence. Most incorporate three main components: (i) specific characteristics or dimensions that reflect the essence of successful PLCs (Stoll et al., 2006; Bolam et al., 2005; Bryk et al., 1999; Hord, 1997, Newmann, 1996; Kruise and Louis, 1993); (ii) factors supporting or inhibiting PLCs creation and sustenance (Atteberry \& Bryk, 2011; Geijsel et al., 2009; Stoll et al. 2006; Bolam et al., 2005; McLaughlin \& Talbert, 2001; Mitchell \& Sackney, 2000; Bryk et al., 1999; Kruse and Louis, 1993); and (iii) phases of development or stages of maturity of PLCs (Bolam. et al. 2005; Fullan, 1991).

Three main differences underlie the existing conceptualizations. First, they consider different essential characteristics (also called dimensions) of PLCs. Appendix I highlights the characteristics-dimensions considered essential by different conceptualizations established since 1993. Initial conceptualizations proposed by Kruise and Louis (1993) and Newmann (1996) focus on five key elements of PLCs: shared norms and values, focus on student learning, reflective dialogue, deprivatization of practice and collaboration. Table 1 provides definitions for each of these five characteristics. Later studies built on this initial conceptualization to propose additional essential characteristics while maintaining some or most of the original five characteristics. While scholars may consider different essential dimensions, there is a congruence around the five essential characteristics originally proposed by Kruse and Louis (1993) and Newmann (1996). Only a few quantitative studies from Western contexts have explored empirically the five characteristics, all of which confirmed them as critical to PLCs (Bolam et al., 2005; Bryk et al., 1999; Louis \& Marks, 1998). 


\section{Table 1: Definition of Five Essential Characteristics of Professional Learning Communities}

$\begin{array}{ll}\text { Shared norms and values } & \begin{array}{l}\text { Staff share beliefs about children and their ability to learn, beliefs about the } \\ \text { proper roles of teachers, parents, and administrators, and beliefs } \\ \text { concerning the use of time and space within the school. }\end{array} \\ \text { Focus on student learning } & \begin{array}{l}\text { Staff members have a sustained and undeviating focus on student learning. } \\ \text { Focus on student learning reflects the idea that PLCs should not simply } \\ \text { ensure that students are taught but PLCs should also ensure that students } \\ \text { learn. }\end{array} \\ \text { Reflective dialogue } & \begin{array}{l}\text { Recurring dialogue holds practice, pedagogy and student learning under } \\ \text { scrutiny. It implies both self-critique and institutional-critique as teachers } \\ \text { work towards discoveries concerning their own learning and practice. }\end{array} \\ \text { De-privatization of } & \begin{array}{l}\text { Teachers practice and talk about teaching in public ways. It includes not } \\ \text { only peer observation of practice and feedback, but also opened dialogue } \\ \text { about individual teachers' practices where teachers share their successes } \\ \text { and learn from their disappointments. }\end{array} \\ \text { Collaboration } & \begin{array}{l}\text { Involves teachers sharing expertise and working together to produce } \\ \text { materials and activities for improved curriculum and pedagogy. }\end{array}\end{array}$

Sources: Kruise and Louis (1993) and Newmann (1996)

Second, conceptualizations differ on which supporting or inhibiting factors are considered and how they are categorized ${ }^{3}$. Categories emphasized in the literature include external factors, internal factors, organizational factors, structural conditions, school context and school composition. Third, the same element may be conceptualized in different ways. An element may be considered an essential characteristic in one conceptualization and as a supportive factor in another one. For example, having mutual trust-collegial relationships is considered an essential characteristic by Stoll et al. (2006), as a supportive condition by Kruse and Louis (1993) and Hord (1997) and as an organizational factor by Bryk et al. (1999).

\section{Limitations of existing conceptualizations}

\footnotetext{
${ }^{3}$ Factors highlighted in the literature include: national policy framework (Bolam et al., 2005), policy decisions (Stoll et al. 2006), school size, (Bryk, 1999), school leaders support PLCs and share leadership (Geijsel et al., 2009; Bolam et al., 2005; Mitchell \& Sackney, 2000; Bryk et al., 1999; Kruse and Louis, 1993), trust, respect, support and inclusive membership (Atteberry \& Bryk, 2011; McLaughlin \& Talbert, 2001; Stoll et al., 2006; Bryk, 1999; Kruse and Luis, 1993) racial diversity, gender composition, workforce turnover (Bryk, 1999), availability of resources in the school, such as time and space to meet, information and materials (Atteberry \& Bryk, 2011; Stoll et al. 2006; Mitchell \& Sackney, 2000), physical proximity (Kruse \& Louis, 1993), communication structures (Kruse \& Louis, 1993) and individual factors, such as personal career interest, experience of stress, antipathy to change and willingness to trust colleagues (Bolam et al., 2005).
} 
A Typology of Professional Learning Communities (PLC) for Sub-Saharan Africa: A Case study of Equatorial Guinea, Ghana, and Nigeria

Despite the advances in PLC conceptualizations, some limitations obtain. First, the multidimensional nature of PLCs and interrelatedness of the different dimensions is not often wellconceived in the literature, contributing to limited conceptual clarity and focus (Sleegers et al., 2013). With the exception of Huffman \& Hipp (2003), few authors have attempted to explicitly identify how the different dimensions of PLCs are inter-related. The multidimensional nature of PLCs has also often been overlooked and only a few studies define PLCs partly in terms of educators' personal capacity, while attention has been paid more to the dimensions of PLCs that underlie the interpersonal capacity of educators (Sleegers et al. 2013). Mitchell and Sackney (2000) and Sackney et al., (2005), who focus on three interdependent capacities - personal, interpersonal, and organizational, are exceptions in this regard. Sleegers et al. (2013) built on the previous work by Mitchell and Sackney (2000) and Sackney et al., (2005) to propose a conceptual model describing these three capacities and added eight underlying dimensions from the literature on PLCs. The level of personal capacity within PLCs is described by reference to two dimensions of active and reflective construction of knowledge and currency. Dimensions underlining the interpersonal capacity include shared values and vision, collective learning, and shared practices. The three dimensions that underlie organizational capacity include, 1) resources, structures and systems; 2) relationships and climate; and 3) stimulating and participative leadership.

Most of the PLC literature is conceptual in nature. There is limited validation of existing conceptualizations in high-resource contexts (excepting by Sleegers et al. 2013; Bolam et al., 2005; Bryk et al., 1999; Louis \& Marks, 1998) and almost no validation in low-and middle-income countries with the exception of Zhang and Pang (2016) and Lee et al (2011) that explore the characteristics of PLCs in Chinese setting. Another limitation of the literature is that it has largely focused on the experience of teachers and PLCs in Western countries, most notably the United States, England and the Netherlands. The scarcity of published PLC research in English from nonEnglish speaking countries has been acknowledged by Toole and Louis (2002)

Still, some findings from this previous research on PLCs in low-and middle-income countries are worth highlighting. Recent studies on South-Africa include a study on teacher collaboration by Abrahams (1997); teacher agency by Brodie (2019), professional learning in private higher education in South Africa (Conje and Blitzer, 2019), and pre-teacher professional learning experiences during rural teacher practice (Nkambile and Mukeredzi, 2017). The potential benefits of the use of peer learning and PLCs in South Africa is reflected in the Council on Higher 
Education publication which states for instance that "research findings indicate that many academics learn through engagement with peers from their departments and disciplines. [....] This means that effective professional development should acknowledge the importance of communities" (Council on Higher Education, 2017, p. 74). Beyond South Africa, we only found one study in Ghana on collaboration between academics and teachers, based on action research, by Pryor (1998) covering an African case. Outside of Africa, there is a paper on constructivist approaches to promote teachers learning (which included learning communities) in Mexico, by Tatto (1999); and Avalos' (1998) study in Chile of teachers participating in Teachers Professional Groups. This emerging literature, however, focuses more on the interaction between PLCs and the broader cultural, political and education contexts in which they are inserted, rather than on how PLCs operate (an exception being the study by Avalos, 1998). Hence, it is not possible to make generalizations about PLC functioning in low-and middle-income countries from this literature base.

Studies by Tatto (1999) and Avalos (1998) indicate that both in Chile and Mexico PLCs did not result from spontaneous teacher action (as it most commonly is the case in developed countries), but rather emerged as part of broader educational reforms that were proposed by educational authorities to the schools. Despite this top-down approach Avalos' (1998) findings suggest that the "contrived collegiality" approach can in fact lead to a culture of collaboration between the teachers. In the conclusion to his large literature study on mathematics teacher professional learning in South Africa, Ndlovu (2018) also proposes PLCs as a bottom-up sustainable teacher driven alternative of learning and highlights that "the notion of PLCs has been embraced at the policy level by both the Department of Basic Education (DBE) and the Department of Higher Education and Training DHET) in the integrated strategic planning framework for teacher education and development (DBE and DHET 2011)". Yet implementation of such communities in practice may be difficult, due to the lack of skilled personnel. Tatto (1999) also highlights the difficulties in developing and sustaining PLCs under Mexico's top-down structure of authority in the educational system. Similarly, Pryor (1998) mentions how the authoritarian and hierarchical systems in Ghana may affect teachers' lack of a sense of their own agency, making any critical reflection on classroom practices irrelevant. Similarly, Brodie (2019) stresses the importance of having agency in choice to stay or leave the PLCs for mathematics teachers in South Africa. Abrahams (1997) emphasizes how apartheid ideology, based on separation, segregation, 
inequality and authoritarianism, permeated the cultures of the schools in South Africa that took part in his study. Feldman (2020) highlights how PLCs could be introduced and be made to function in the post-apartheid landscape. Some of these initial studies seem to indicate that "the empowering values inherent in the notion of professional learning community may conflict with a nation's most basic cultural values or recent political past" (Toole \& Louis, 2002, p. 273). Another issue is that in many low-and middle-income countries, and in Sub-Saharan Africa countries in particular, the initial preparation teachers receive is highly teacher-centered, and extremely didactic and focused on direct transmission of knowledge (Akyeampong et al., 2013; Altinyelken, 2010; Pryor, 1998). This may make teachers' ongoing reflection on their practices and collaboration more challenging due to a discrepancy between the type of preparation they receive to become a teacher and the skills required for effective teachers' collaboration in a PLC.

Most existing conceptualizations consider PLCs as a school-based, organic initiative. They do not account for PLCs that are explicitly and purposefully designed as a part of broader educational reform policies and programs. There is limited discussion on the various ways that schools and school systems might implement a PLC in accordance with the characteristics thought to be essential to it. Hence, existing conceptualizations offer little guidance to practitioners and policy makers. This is problematic in the context of low-and-middle income countries, as PLCs often originate and are an integral part of education systems-policies and-or education development programs. Although the Western literature highlights a common set of essential PLC characteristics, in practice PLCs in developing countries vary greatly in their design. This variability related to PLC designs, however, is not currently accounted for by the existing literature. Given the potential for differences in conceptualization and implementation of PLCs in developed and developing settings, and the limited literature on PLCs in less-developed contexts, this study inductively creates a typology of PLCs that incorporates elements that might be specific to these countries, with a focus on Sub-Saharan Africa.

\section{Section III: Methodology}

This research builds on a multi-method data collection and analysis approach, encompassing document analysis, semi-structured interviews and validation sessions. PLC document collection and content analysis formed the basis of this review. The literature acknowledges that information and insights derived from documents can make valuable contributions to a knowledge base 
(Bowen, 2009). However, although documents have been recognized as important sources in overall qualitative research and specifically in theory-building (Glaser \& Strauss, 1967), it cannot replace other kinds of data (Atkinson \& Coffey, 2004). In our specific case, we cannot learn from documents how a PLC actually operates on a day-by-day basis. Thus, we used semi-structured interviews for triangulation - to validate our findings from the document analysis and add missing perspectives originating from the interview sources. To validate the typology, we conducted discussion sessions with practitioners in PLCs.

\section{Document Search}

We used document analysis for systematically reviewing and evaluating documents on PLCs in Sub-Saharan African countries. Our inclusion criteria were any project or policy document detailing the design of a PLC, with a specific focus on Sub-Saharan African countries; and documents describing PLCs primarily at the primary education levels ${ }^{4}$, though we did encounter examples that included both preschool and primary. We adopted a two-stage approach to search for PLC documents. Because in Sub-Saharan Africa PLCs are often part of education programs promoted by international non-profit organizations in partnership with Ministries of Education, during the first-stage, we contacted key development organizations working in the education field explaining our study and soliciting documents that fell within our inclusion criteria. In a second stage we conducted a broader internet search using specific key words ${ }^{5}$.

\section{Semi-structured interviews}

Upon completion of the document analysis, we conducted semi-structured interviews with four FHI 360 practitioners working on the design and implementation of projects with a PLC component. We adopted a purposive and convenience sample selection approach: (i) we focused

\footnotetext{
${ }^{4}$ The choice to focus on primary education follows a shift in donor priorities in recent years from promoting school attendance to improving quality of education at early grades. PLCs have become more prevalent at the primary education level in Sub-Saharan Africa, as investments in improving teaching quality through pre- and in-service teacher professional development are often completed with a PLC component.

${ }^{5}$ Given there is no common agreed nomenclature for PLCs in the field, we included in our search the following key words, together with "Sub-Saharan Africa": communities of practice, teacher learning circles, communities of inquiry, professional networks, critical friends groups, study groups, teacher research collaboratives, norms of collegiality, teachers' collaboration with colleagues, professional community, learning community, and teacher networks.
} 
on individuals directly involved in the same programs from which many of the documents for the prior stage were drawn; and (ii) we only selected FHI 360 practitioners, as the relationship of the authors with organization facilitated the interview process ${ }^{6}$. The purpose of the interviews was to triangulate information and assess whether our findings from the document analysis was perceived similarly or differently by the practitioners. The semi-structured interviews allowed us to explore in further depth specific aspects that emerged in the document analysis. Finally, through the semistructured interviews we asked to what extent PLCs incorporate the five core characteristics highlighted in the literature. For the questions on the core characteristics, we asked the interviewees to rate the strength of the each of the five characteristics in their PLC through a series of questions using a scale of $1-3^{7}$. At the end, we were able to calculate an average score indicating the overall strength of the PLC.

\section{Validation sessions with practitioners}

The document analysis and semi-structured interviews informed the design of an initial PLC typology and a PLC framework. Subsequently, we conducted seven discussion sessions with nine FHI 360 practitioners on PLCs guided by semi-structured questions to establish theoretical validity. Although the typology was informed by the experience of Sub-Saharan African countries we included in the discussion sessions practitioners of PLCs in Africa who had experience of PLC in African countries as well as in Latin American countries to benefit from their cross-continental practical experience on the topic. In total, we conducted six PLC validation sessions, with practitioners working on projects in Equatorial Guinea, Ghana, and Nigeria. We conducted one additional session with a senior technical staff who oversees a portfolio of projects. The practitioners participating in the sessions consented verbally before the meeting. The authors took notes of the discussions and analyzed it afterwards.

\footnotetext{
${ }^{6}$ All practitioners being from FHI could potentially result in a bias. However, their participation in the semistructured interviews was not meant to build the PLC conceptualization. Rather, their role was to give meaning to the conceptualization developed from the document review and inform us if something was missing from review. Because of the role the semi-structured interviews played in this research, it is unlikely that our sample selection approach resulted in any bias.

${ }^{7}$ The scale for questions related to the core characteristics as follows: The project 1) does not recognize this practice under the PLC design or promote it, 2) recognizes this practice under the PLC design but does not consistently promote it, 3) explicitly recognizes and consistently promotes this PLC practice.
} 


\section{Data analysis}

We adopted an inductive content analysis approach to analyze the documents and the interview notes according to those themes that emerged from the data from repeated examination and comparison. We adopted a two-stage analytic strategy. In the first stage we analyzed the documents using an inductive approach to identify patterns in the data by means of thematic codes (Bowen, 2009; Corbin \& Strauss, 2008). The recognized patterns within the data and the themes that were identified became the categories for analysis (Fereday \& Muir-Cochrane, 2006). By employing an inter-comparison of documents (constant comparison), we identified and described salient patterns. In this process, we looked for substantive significance-consistency of themes across documents (and not necessarily its frequency). This inductive coding approach allows themes to emerge directly from the data, capturing elements of PLCs that may be unique to Sub-Saharan African countries and hence not previously considered by existing conceptualizations. In the second stage we developed and defined codes based on close reading of the document and notes to represent the identified themes (Greg et al., 2012). Subsequently, all text was coded using the code-list. In this second stage the data was abstracted further using grounded theory technique. We compared and contrasted themes, identifying structure among them (Bernard \& Ryan, 1998). In this process, we analyzed how key themes were inter-related and sorted them into models (or generic categories) with similar content, generating a PLC typology. We checked the typology again against the data to ensure that our interpretation is supported and grounded in our data (Greg et al., 2012; Bernard \& Ryan, 1998).

\section{Section IV: Findings}

Our document search resulted in 36 documents representing eight programs with a PLC component in seven countries in Sub-Saharan Africa; Democratic Republic of Congo, Equatorial Guinea, Ghana, Nigeria, Senegal, South Africa and Tanzania, as well as documents from the International Network for Education in Emergencies (INEE), which are available for use in many contexts. Seven out of the 36 documents were found via internet search, while the remaining were shared by the nonprofits we contacted. Four main development organizations (Family Health International 360, International Rescue Committee, Chemonics International and VVOB Education for Development), in partnership with national or local education authorities, produced the documents included in the analysis. Types of documents reviewed in the process are: PLC 
A Typology of Professional Learning Communities (PLC) for Sub-Saharan Africa: A Case study of Equatorial Guinea, Ghana, and Nigeria

design documents, PLC guidelines, PLC guides or PLC manuals, project proposals, project design documents, policy briefs or white papers describing PLCs. The documents' length ranged from 1 to 282 pages with an average length of 32 pages. Most often these documents were issued by Ministries of Education or other local education authorities or by development organizations with education programs in Sub-Saharan Africa. Appendix II provides a list of the documents reviewed.

Certain PLC elements consistently appeared in most or all documents reviewed, but with a lot of variation. Table 2 highlights the themes that emerged from comparing shared elements across documents. The first theme is the type of grouping. PLCs' grouping (who can participate in the PLC) is a recurring theme. But PLCs are organized in different ways in different countries; some PLCs are school-based and only include teachers from the same school while others are comprised of teachers from a cluster of geographically close schools. Within school-based or cluster-based PLCs, we also observe variation regarding teacher inclusion based on grade (some PLCs only include teachers for specific grades while others involve teachers of all grades, i.e., class or year), and subject (some PLCs are focused on mathematics or language while others do not make a distinction). Frequency of PLC meetings, meeting length (or duration) and size of PLC group also consistently appeared in most documents reviewed, but with a lot of variation (e.g., recommended meeting frequency varied from weekly to monthly; meeting duration varied from 30 minutes to 8 hours). Also, some PLCs offer incentives to teachers' participation, although the type of incentive varies greatly (from financial incentives, such as a travel stipend, to professional incentives, such as professional development credit). The type of material used to guide the PLC meetings varied in their level of structure and prescriptiveness.

The theme "material" emerged by analyzing the materials themselves rather than by looking for recurring patterns in the text of the documents. Scripted materials are those materials that pre-define the topics of each PLC meeting, specific activities to be conducted within the meetings, and how the meetings should be facilitated. If the material is less prescriptive and only includes step-by-step approaches or suggested topics of discussion, we classify them as "guidelines." Some of the PLCs under analysis did not have a set of materials to guide the discussion, which was left entirely to the PLC members to decide. Facilitation was a recurring but variable theme across the documents. Some PLCs have a facilitator responsible for leading the technical discussion (who usually receives prior training), while in others, the facilitator is responsible for administrative aspects (taking attendance, registering notes, scheduling meetings, 
etc). We call the former a "technical facilitator" and the later an "administrative facilitator." We also observe cases where the facilitator plays both roles, or where there is no designated facilitator and teachers in a PLC take turns in facilitation responsibilities.

\section{Table 2: Main themes from PLC document analysis}

- $\quad$ School-based (PLCs comprised by teachers from the same school)

\begin{tabular}{|c|c|}
\hline $\begin{array}{l}\text { Type } \\
\text { Grouping }\end{array}$ & $\begin{array}{l}\text { or cluster-based (PLCs comprised by teachers from a group of } \\
\text { schools that are geographically nearby) } \\
\text { - Organized by grade level, subject or mix of both }\end{array}$ \\
\hline $\begin{array}{l}\text { Meeting } \\
\text { Frequency }\end{array}$ & - Weekly, bi-weekly and monthly meetings \\
\hline Meeting Length & - $\quad$ Meetings from $0.5-8$ hours \\
\hline Group size & $\begin{array}{l}\text { - Depends on the \# of teachers in school or cluster. } \\
\text { - } \quad \text { Range of } 2 \text { to } 70 \text {, average size is } 20\end{array}$ \\
\hline Material & $\begin{array}{l}\text { - Scripted materials with pre-defined topics of discussion and } \\
\text { approach. } \\
\text { - Meeting guidelines with step-by-step approaches or suggested topics } \\
\text { of discussion } \\
\text { - No set materials }\end{array}$ \\
\hline Incentives & $\begin{array}{ll}\text { - } & \text { Travel stipend (for cluster-based) } \\
\text { - } & \text { Food/refreshments } \\
\text { - } & \text { Basic supplies (notebooks, pencils, etc) } \\
\text { - } & \text { Professional development credit }\end{array}$ \\
\hline Facilitation & $\begin{array}{l}\text { - Technical facilitators. } \\
\text { - Administrative facilitators (taking attendance/notes). } \\
\text { - } \quad \text { Facilitators may or may not receive prior training. } \\
\text { - No designated facilitator. }\end{array}$ \\
\hline External expert & $\begin{array}{l}\text { - May or may not involve specialist input in subject/pedagogical } \\
\text { knowledge to enhance the technical discussion. }\end{array}$ \\
\hline $\begin{array}{l}\text { Professional } \\
\text { development }\end{array}$ & $\begin{array}{l}\text { - } \quad \text { PLCs as stand-alone } \\
\text { - PLCs part of a broader professional development program }\end{array}$ \\
\hline
\end{tabular}
Source: Own data

The semi-structured interviews confirmed the themes and patterns found in the initial document analysis. Table 3 summarizes the findings from the semi-structured interviews. During the interviews, we explored the main themes from the document analysis in each of the four project examples. This data also helped us to confirm the classification of each PLC model. In addition to showing the variation across the themes listed above, Table 3 shows the overall score for the core characteristics of each PLC example. All four examples were in a mid-range of 2, which meant that they recognize a particular practice linked to the core characteristic, but are not consistently implementing it in the PLC. This could also be because all four of the PLCs examined 
A Typology of Professional Learning Communities (PLC) for Sub-Saharan Africa: A Case study of Equatorial Guinea, Ghana, and Nigeria

were relatively new and part of teacher development projects that brought the PLC component to teachers' practice. 
Table 3: PLC classification based on document analysis and semi-structured interviews for four projects

\begin{tabular}{|c|c|c|c|c|}
\hline & Ghana Learning & Nigeria RANA & $\begin{array}{l}\text { Equatorial Guinea, } \\
\text { PRODEGE }\end{array}$ & Senegal, Passerelles \\
\hline PLC terminology & $\begin{array}{l}\text { School-based INSET } \\
\text { meetings }\end{array}$ & $\begin{array}{l}\text { Weekly school } \\
\text { meetings }\end{array}$ & Teacher circles/networks & Pedagogical cluster \\
\hline \multicolumn{5}{|l|}{ Core characteristics $^{8}$} \\
\hline Shared norms and values & 2.6 & 2 & 3 & 3 \\
\hline Focus on student learning & 2 & 1.5 & 2.5 & 2.5 \\
\hline Reflective dialogue & 2.5 & 2 & 2 & 2.5 \\
\hline Deprivatization of practice & 2.6 & 2.6 & 2.3 & 2.3 \\
\hline Collaboration & 2 & 1.6 & 1.3 & 2.3 \\
\hline Average score (1=low, $3=$ high) & 2.3 & 1.9 & 2.2 & 2.5 \\
\hline \multicolumn{5}{|l|}{ Structural varying features } \\
\hline Type of Grouping & School-based & School-based & Cluster-based & $\begin{array}{l}\text { School-based and } \\
\text { Cluster-based }\end{array}$ \\
\hline Meeting Frequency & Weekly & Weekly & Bi-monthly & Monthly \\
\hline Meeting Length & $1 \mathrm{hr}$ & $1 \mathrm{hr}$ & $4 \mathrm{hrs}$ & $1-2 \mathrm{hrs}$ \\
\hline Group size (average) & $4-10$ & $4-8$ & $20-30$ & Varies \\
\hline Material & $\begin{array}{l}\text { Scripted materials } \\
\text { Meeting guidelines }\end{array}$ & $\begin{array}{l}\text { Meeting guidelines } \\
\text { Meeting log }\end{array}$ & Scripted materials & $\begin{array}{l}\text { Meeting guidelines } \\
\text { Coaching rubric }\end{array}$ \\
\hline Incentives & $\begin{array}{l}\text { Professional development } \\
\text { credit }\end{array}$ & None & $\begin{array}{ll}\text { - } & \text { Travel stipend } \\
\text { - } & \text { Basic supplies } \\
\text { - } & \text { Professional development } \\
\text { credit }\end{array}$ & None \\
\hline Facilitation & $\begin{array}{ll}\text { - } & \text { Technical and } \\
\text { administrative facilitator } \\
\text { - } & \text { No training } \\
\text { - } & \text { Head teacher or } \\
\text { volunteer teacher }\end{array}$ & $\begin{array}{l}\text { Technical and } \\
\text { administrative } \\
\text { facilitator } \\
\text { - Receives } \\
\text { training } \\
\text { - } \quad \text { Lead teacher }\end{array}$ & $\begin{array}{l}\text { - Technical and } \\
\text { administrative facilitator } \\
\text { - } \quad \text { Receives training } \\
\text { - } \quad \text { Experienced teacher }\end{array}$ & $\begin{array}{ll}\text { - } & \text { Technical and } \\
\text { administrative } \\
\text { facilitator } \\
\text { - } & \text { Receives training } \\
\text { - } & \text { Experienced } \\
\text { teacher or director }\end{array}$ \\
\hline External expert & None & None & None & $\begin{array}{l}\text { For specific subject } \\
\text { content area }\end{array}$ \\
\hline Professional development & $\begin{array}{l}\text { Part of a broader TPD } \\
\text { program }\end{array}$ & $\begin{array}{l}\text { Part of a broader } \\
\text { TPD program }\end{array}$ & Part of a broader TPD program & $\begin{array}{l}\text { Part of a broader TPD } \\
\text { program }\end{array}$ \\
\hline \multicolumn{5}{|l|}{ Supporting Conditions } \\
\hline & - Leadership support & $\begin{array}{l}\text { - } \quad \text { Leadership } \\
\text { support } \\
\text { - } \quad \text { Built in meeting } \\
\text { time }\end{array}$ & - $\quad$ Leadership support & $\begin{array}{l}\text { - Leadership } \\
\text { support } \\
\text { - } \quad \text { Built in meeting } \\
\text { time }\end{array}$ \\
\hline \multicolumn{5}{|l|}{ Phases of development } \\
\hline & $\begin{array}{l}\text { Implementation (structure is } \\
\text { institutionalized in system) }\end{array}$ & Implementation & Implementation & Initiation $^{9}$ \\
\hline \multicolumn{5}{|l|}{ Model } \\
\hline & Scripted to structured & Structured & Scripted & Structured \\
\hline
\end{tabular}

Source: Own data

\footnotetext{
${ }^{8}$ The scale for questions related to the core characteristics is as follows: The project 1) does not recognize this practice under the PLC design or promote it, 2) recognizes this practice under the PLC design but does not consistently promote it, 3) explicitly recognizes and consistently promotes this PLC practice.

${ }^{9}$ The Passerelles Project was just initiating at the time of the interview. Answers are based on the intended design of the PLC and are not a reflection of what had been occurring. Thus, the PLC is still in an "initiation" phase of development even though the core characteristics reflected in the design are strong.
} 
Interviewees confirmed the variation in type of groupings, as half of the examples they offered had school-based meetings and half cluster-based meetings. All the PLC examples from the interviews originated from broader teacher development program, but the composition of the groups varied like what we saw in the document analysis. For example, all teachers in grades 1-3 in the Nigeria Reading and Numeracy Activity (RANA) program, who received training in literacy and numeracy through the program, participated together in the weekly meetings. In the PLCs promoted by the Program for Educational Development of Equatorial Guinea (PRODEGE), all primary and preschool teachers, regardless of grade-level, were grouped together in geographic clusters as part of a national pedagogical certificate program. In terms of the meeting frequency and length of meeting, the interviews also confirmed variation. From the interviews, we find that the less frequent the meetings (monthly or bi-monthly as opposed to weekly) led to longer meeting times. Equatorial Guinea's bimonthly PLC meetings are four hours long, while Ghana, Nigeria and Senegal promote one to two-hour weekly meetings. Group size also varied greatly across the examples from the interviews and were largely driven by the number of teachers participating in the Teacher Professional Development (TPD) program in a school or geographic area.

The interviews allowed us to deepen our understanding of the use of "materials", specifically the types of materials used, the level of structure and whether or not a material can be categorized as "scripted." All cases discussed in the interviews used either a material that provided basic guidelines for the meeting, such as in Nigeria and Senegal; or a heavily scripted material, such as in the case of Ghana and Equatorial Guinea. In terms of the "facilitation" characteristic, all the PLC examples from the interviews did have a facilitator, but the type of facilitator and designation level of training varied. For example, in Ghana, the facilitators received no prior training on their facilitation role, while in Nigeria, Senegal, and Equatorial Guinea, the facilitators all received training through the projects. Facilitator could be head teachers, lead teachers or volunteer teacher from the group.

The interviews allowed us to understand more deeply the influence of incentive or its absence on the PLC model as a supporting condition. Knowing what supporting conditions can foster teachers' participation in PLCs is helpful for Ministries of Education, donors and education practitioners to consider when designing education reforms or teacher professional development programs. For example, in Ghana, the interviewee spoke of the importance of receiving professional development credit for initiating PLCs and keeping the teachers motivated to continue 
their participation. In Equatorial Guinea, the teachers receive several incentives (travel stipends, professional development credit, and basic supplies) in order to encourage participation in the PLCs. On the other end of the spectrum, in Nigeria and Senegal, no incentives are provided, and the lack of an incentive was not mentioned as one of the barriers or challenges to the teachers' consistent participation in the PLCs. The findings seem to indicate that offering an incentive at the onset might help to establish or create a demand for PLCs in an education system. However, if the incentive is removed, the PLC might end if the teachers do not have the intrinsic motivation to meet.

During the semi-structured interviews, we also explored the supporting conditions and barriers for establishing and sustaining PLCs. For Senegal, the interviewee stressed the importance of building positive interpersonal relationships with the teachers as an enabling factor for establishing as well as sustaining a PLCs. The document analysis, and specifically the training materials and PLC guides from various projects, also revealed that many of the programs stressed the importance of building a cohesive peer support group from the onset by incorporating specific team-building exercises in the facilitator training or PLC meetings during the first sessions. Another interviewee stressed the importance of building in enough time for training the facilitators in order to ensure the success of PLCs. The training needs to be practical and purposeful for teachers to be able to lead successful meetings, particularly under a non-scripted model, as in the case of Nigeria.

In the second stage, we abstracted the data further to identify key determinants of the internal PLC dynamic and of teachers' level of autonomy. We compared and sorted a few themes into three emergent conceptual categories of PLCs. We defined three models of PLCs that can explain practices in Sub-Saharan Africa, namely the Autonomous PLC, the Structured PLC and the Scripted PLC.

Table 4: Emerging typology: three models of PLC

\begin{tabular}{ll}
\hline Autonomous PLCs. & $\begin{array}{l}\text { Material (no external materials provided). Incentives (no incentives). Professional } \\
\text { development (stand-alone). }\end{array}$ \\
Structured PLCs. & $\begin{array}{l}\text { Material (structured steps; general guidelines). Incentives (stipend/incentive may be } \\
\text { provided). Professional Development (may be stand-alone or part of a broader professional } \\
\text { development program). }\end{array}$ \\
& $\begin{array}{l}\text { Material (highly scripted guides). Incentives (stipend/incentive may be provided). } \\
\text { Professional Development (part of a broader professional development program). }\end{array}$ \\
\hline
\end{tabular}

Source: Own data 
According to the autonomous model teachers identify their own starting points, learning needs, the focus and objectives of their learning (so they can focus on issues important to them), as well as the pace and scope of the PLC. Autonomous models of PLC tend to emerge organically and naturally within schools (hence are not part of structured professional development interventions). They do not rely on external materials to guide or dictate the discussions and do not provide incentives to teachers, who are self-motivated to participate. The documents analyzed did not contain an example of a fully autonomous model. Nonetheless, descriptions of how PLCs function from the Western literature indicate that this model is dominant in high-resource contexts.

In the structured PLC model, teachers receive materials highlighting a structure or series of steps to guide their dialogue within the learning community. Teachers may or may not receive financial or other sorts of incentive to participate. Structured PLCs can be a stand-alone intervention (e.g., promoted by a Ministry of Education or other local education authority through the provision of guidelines), or they may be part of a professional development initiative, where the PLCs serve to reinforce and contextualize knowledge-practices taught as part of the broader program. In this model, teachers maintain some level of autonomy, but within the proposed structure. PLCs in Nigeria, for example, follow a six-step approach to each 60-minute meeting, consisting of:

1) Opening: Letter sound movement or song (3 minutes)

2) Discussion: A weekly success (2 minutes)

3) Discussion: A weekly challenge (5 minutes)

4) Practice: One instructional skill (letter blending, reading aloud, etc.) (10 minutes)

5) Practice lesson for the upcoming week (30 minutes)

6) Feedback on practice lesson (5 minutes)

Within this proposed structure, teachers can choose the topics for weekly successes and challenges and which instructional skills they would like to practice. PLCs in South Africa also promote a structure, but for a series of meetings, as opposed to each PLC meeting (Table 5). PLCs start with meetings focused on access and motivation and gradually, as members start to get to know each 
other, move on to meetings focused on constructing knowledge together and critically reflecting and inquiring.

Table 5: PLC structure in South Africa:

\begin{tabular}{|l|l|l|l|l|l|}
\hline & & Stage 2 & Stage 3 & Stage 4 & Stage 5 \\
\hline Focus & $\begin{array}{l}\text { Access \& } \\
\text { Motivation }\end{array}$ & Socialization & $\begin{array}{l}\text { Information } \\
\text { Exchange }\end{array}$ & $\begin{array}{l}\text { Knowledge } \\
\text { Construction }\end{array}$ & $\begin{array}{l}\text { Development } \\
\text { (Reflection) }\end{array}$ \\
\hline $\begin{array}{l}\text { Approx. } \\
\text { duration }\end{array}$ & 2 meetings & 2 meetings & Variable & Variable \\
\hline Activities & $\begin{array}{l}\text { - Facilitating } \\
\text { - Icebreakers } \\
\text { - Discussing } \\
\text { rules }\end{array}$ & $\begin{array}{l}\text { - Getting to know } \\
\text { each other. } \\
\text { - Develop shared } \\
\text { understanding } \\
\text { on PLCs. } \\
\text { - Developing } \\
\text { mission \& vision }\end{array}$ & $\begin{array}{l}\text { - Presenting and } \\
\text { discussing results of } \\
\text { individual tasks. } \\
\text { - Exchanging } \\
\text { teaching } \\
\text { resources }\end{array}$ & $\begin{array}{l}\text { - Discuss questions for } \\
\text { - Development of } \\
\text { resources in effective } \\
\text { work teams. } \\
\text { - Lesson study } \\
\text { - Error analysis }\end{array}$ & $\begin{array}{l}\text { - Exploring the } \\
\text { use of new } \\
\text { materials and } \\
\text { technologies }\end{array}$ \\
\hline
\end{tabular}

Source: Professional Learning Communities: A Guideline for South African Schools

In the third PLC model, scripted, PLCs receive scripted materials that pre-define the objective, focus, topics, learning exercises and dynamic of the meetings and sometimes frequency with which meetings should take place. In this model materials are stand-alone so that teachers can facilitate their own learning and reflection using the scripts provided. Scripted PLCs reinforce knowledge-practices taught by a broader professional development program or act as channel for promoting instruction associated with curriculum reforms. As with structured PLCs, they may or may not provide incentives for participation. Equatorial Guinea and Ghana are countries where scripted PLCs are practiced. In Equatorial Guinea, the Program for Educational Development (PRODEGE) developed scripted guides that dictate the agenda and activities for the four-hour bimonthly meetings. The PLCs are part of a national teacher professional development program in which the preschool and primary teachers who successfully complete the requirements receive a pedagogical aptitude certificate. Given the requirements of the Teacher Professional Development (TPD) program, all the content for the meetings is pre-defined in order to cover the required content of the program which is divided into four thematic areas. For example, the guides for the first thematic area of the TPD program guide the teachers through a series of scripted activities related to basic pedagogical theory that supports active learning methodology, which is the backbone of the PRODEGE intervention. The three thematic areas that follow are subject-specific: pedagogy of mathematics, language and social and natural sciences. Since teachers are grouped by either preschool-level or primary-level, PRODEGE developed specific guides for each education level following the same thematic area. The types of activities in the guides vary from 
reading a text and discussing what was learned in groups or pairs, to sharing related practical classroom examples with peers and planning together how the teachers will apply the new knowledge in their own classrooms. The hope is that the certificate will motivate teachers to participate in the PLCs, connect teachers who were previously isolated, and create peer support networks nationwide that can be sustained beyond the project.

Similarly, in Ghana, the Learning project initially provided scripted materials that dictate the topic, content and timing of each PLC meeting. The Ghana materials developed for PLC meetings define a specific topic related to early grade reading instruction for each week, and lead teachers through activities, such as discussion, planning, with their suggested timing for each hourlong meeting. The content reinforced the training in early grade literacy that teachers had received and helped facilitate discussion on the new methodology. The meeting guides offered prompts for facilitators to follow in order to help guide each meeting. Given the highly scripted nature of these materials used at the onset of the project, Ghana PLCs can be categorized as scripted. However, the semi-structured interview revealed that changes between models can occur in practice. During implementation of the Ghana Learning PLC model, the project team found that many teachers did not participate in the meetings or did not use the meeting materials consistently. Thus, later in the project cycle, the Learning project released revised PLC materials for meetings that took on a more structured approach in order to give teachers more flexibility in choosing the topics most relevant to them for discussion with peers. This change signals a move from the scripted model to a more structured model.

\section{Section V: An integrated conceptual framework of PLCs}

In this section, we present the conceptual framework of PLCs that integrates the PLC typology and varying features of PLC that emerged from our qualitative research in Sub-Saharan Africa countries with key elements proposed by the Western literature. It includes a five-dimension framework that integrates the three dimensions from the academic literature (core characteristics, supportive conditions and stages of maturity) with two new dimensions found in our qualitative research in Sub-Saharan Africa countries research (PLC model and structural varying features). These dimensions can be visualized in Figure 1 as the five circles. While each structural varying feature may or may not be important in explaining PLCs in Sub-Saharan Africa, the type of model is essential to understanding their design and operation. 
Figure 1: Framework of Professional Learning Communities

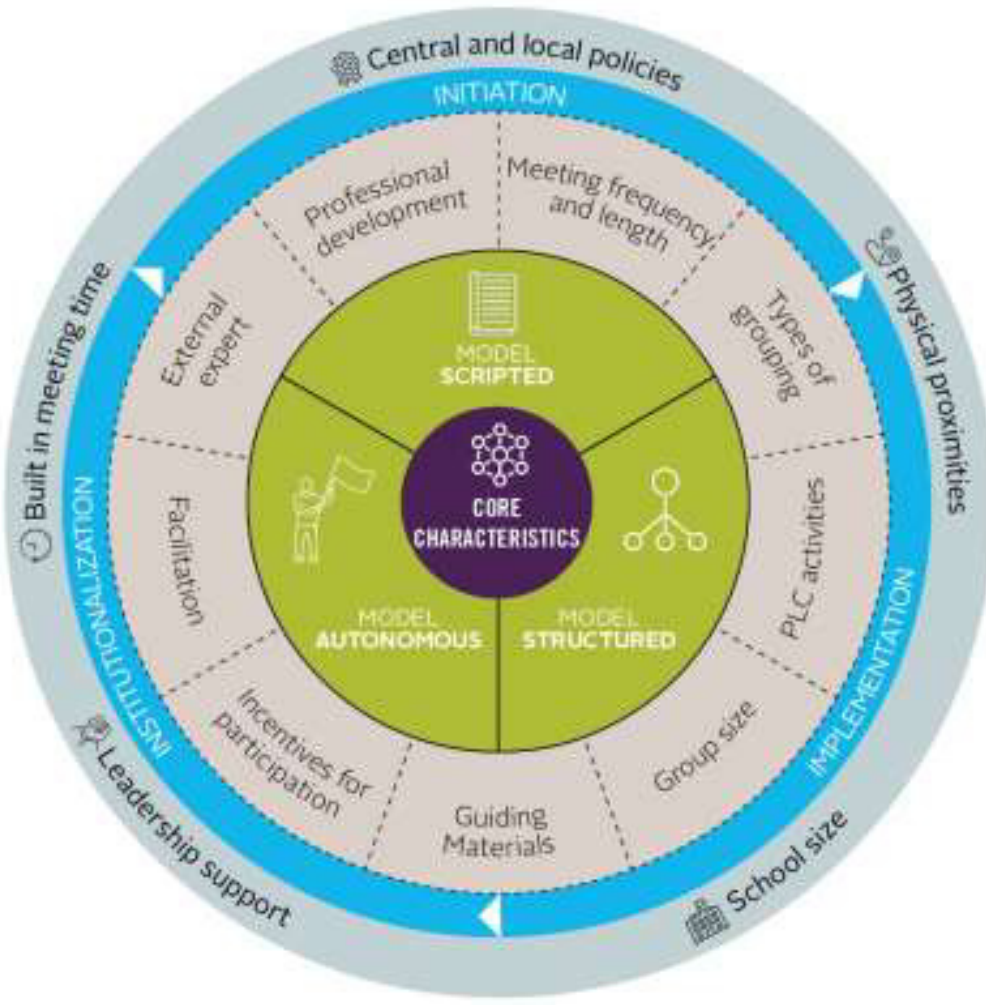

Core characteristics

PLC models

Structural varying features

Phases of development

Supportive conditions

At the very center of the framework are the core characteristics of PLCs, which are the characteristics any PLC should have to be successful, regardless of the model or specific design it adopts. They refer to the five essential characteristics that received the most support in the Western PLC literature: shared norms and values; focus on student learning, reflective dialogue, deprivatization of practice, and collaboration. Although in our document analysis does not show much evidence of the five core characteristics in Sub-Saharan Africa PLCs, the semi-structured model revealed that these characteristics are being implicitly considered in the design and implementation of the PLCs. We maintain the five characteristics in the framework but acknowledge that further empirical tests in the context of low-and middle-income countries are needed to better understand their role in PLCs in these countries.

PLC models are directly related to the types of materials and the extent to which these materials influence the level of PLC autonomy and structure. By categorizing PLCs into three different models and acknowledging their variability in this aspect, the framework incorporates 
modes of PLC operation that are specific to Sub-Saharan African countries, and possibly to lowand middle-income countries more generally. The autonomous model, which emphasizes teachers' autonomy and authority in making decisions regarding the processes, agenda and objective of their learning communities, is the dominant model in developed countries. The autonomous model, however, does not reflect how PLCs operate in Sub-Saharan African countries, where highly structured or scripted learning communities guided by pre-developed materials prevail. While the three models - scripted, structured and autonomous - are defined by their overall level of structure and outside influence on the community (usually through materials), specific features of PLCs can vary greatly within any model. The third dimension of our framework refers to structural varying features; the different elements associated with how PLCs are designed that might vary across PLC models. The features included in our framework refer to the themes that emerged from the document analysis, presented in Table 2: (i) type of grouping; (ii) meeting frequency and length; (iii) group size; (iv) guiding materials; (v) facilitation; (vi) incentives for participation; (vii) professional development; and (viii) external expert.

The fourth dimension of the framework refers to the phases of development and reflects PLCs' evolving and fluid, rather than static, nature (Stoll et al., 2006; Fullan, 1991). It recognizes that sustainability of PLCs within schools or among clusters of schools depends on how well staff can sustain their efforts and how embedded PLCs are into the culture of their schools (or cluster of schools) (Huffman \& Hipp, 2003). The framework incorporates three phases of change proposed by Fullan (1991): initiation, implementation and institutionalization. This dimension is directly related to the PLC core characteristics of our framework and reflect their level of development and institutionalization within a school or cluster of schools. Some schools or clusters of schools may be at very early stages of developing the characteristics of a PLC or may be further along in the implementation process. In an institutionalized PLC, the five characteristics become embedded into the culture of the school or cluster of schools.

Constituting part of the fifth dimension are the different supportive conditions related to organizational factors, structural conditions, and overall context. Supportive conditions are external factors that may enable or inhibit the creation, development, ongoing management and sustainability of PLCs (Bolam et al., 2005). As such, although internal PLC characteristics may foster or hinder PLC work (e.g., mutual trust, PLC composition related diversity and background), in this dimension we focus on external factors only. Included are factors that seem particularly 
relevant to the Sub-Saharan African context. A first supportive condition is built in meeting time: if teachers do not have meeting time built into the school calendar, there is a risk that meetings or other forms of collaboration will be canceled or will not take place. Time for PLCs' meetings "cannot be simply tacked onto the ends of already tiring school days" (Kruse \& Louis, 1993, p. 16) and teachers must be able to consistently allocate time to such meetings. Building time into the school calendar for PLCs to meet can result from school-level organization decisions or enactment of policies at the system-level. A second condition is physical proximity and-or devoted space. Teachers that are part of cluster-based PLCs may find it easier and may be more motivated to travel and meet if the meeting location is close by. For school-based PLCs, having physical spaces devoted to faculty meetings may increase teacher contact and minimize interruptions. A third often-cited condition is leadership support. Principal and headteachers play a key role in creating a school culture that fosters and generates opportunities for collaboration among teachers and continuous learning (although they cannot ensure it will happen). A fourth condition that may be especially relevant for low- and middle- income countries is school size. Small schools can constitute engaging work environments that facilitate the communication flow (Bryk et al., 1999). Schools that are too small, however, may not have enough teachers to collaborate in school-based PLCs. This may be the case for some multigrade schools in rural parts of Sub-Saharan Africa. The final condition refers to central and local policies. Central and local policies may provide incentives for Continued Professional Development (CDP) or credit towards it, may affect resource allocation to schools, may or may not allocate a certain number of hours for teachers' planning and collaboration, and may change the focus away from collaboration by placing emphasis on performance measured by student achievement.

\section{Validation sessions with practitioners}

After developing this draft framework, we conducted discussions with staff who had direct experience working on projects that implemented PLCs to solicit their feedback on the "fit" of the framework to the context in which they work. Overall, the practitioners agreed that the framework developed represented PLC operations well, and they validated the categories included in the frame. School leadership support was a condition highly emphasized by practitioners as a critical one for enabling and sustaining PLCs in Sub-Saharan Africa. One individual mentioned that "school principals play a critical role in supporting teachers' participation within PLCs." 
When discussing the PLC model phases and some varying features, practitioners highlighted that a scripted PLC model guiding participants may be beneficial for initiating PLCs, while the ultimate goal for sustainability purposes would be for PLCs to become fully autonomous in order to be institutionalized. The practitioners also mentioned that in terms of the type of grouping, clusterbased PLCs that build on an established education system's organizational structure (e.g., schools already grouped together for administrative purposes) may help sustain the PLC without the outside support of a project or professional development program.

One element not previously considered in the framework was brought up. According to one interviewee:

we should consider adding to the typology what activity occurs during the PLC meetings. For example, do teachers use the time to look at student work, develop lesson plans, model lessons, conduct peer observation, or is time used just for reflection?

While the feature "Activities" did not emerge from the document and interview analysis, further research is needed to investigate if indeed this is a relevant component of PLCs that should be integrated into the framework.

\section{Section VI: Discussion}

In this paper we propose a typology of PLCs' that captures three PLC models - autonomous, structured and scripted - accounting for modes of PLC operation in Sub-Saharan African countries. Although we aimed to develop a typology that reflects how PLCs function in low- and middle-income countries, and especially in Sub-Saharan African countries, the final typology also holds for developed countries. While in low- and middle-income countries the structured and scripted models of PLC prevail, in developed countries the autonomous model is more commonly found. Indeed, the Western literature highly emphasizes teachers' autonomy and the importance of teachers' ability to make decisions regarding the processes of their learning communities. We can also find structured models of PLCs in developed countries, although less frequently.

Our document analysis revealed that within any of the three models, specific features of PLCs can vary greatly, so we also account for structural varying features, which refer to all the distinctive features associated with how PLCs are designed that might vary across PLCs. There are also key differences between high and low-resource contexts in terms of structural varying 
features that the typology incorporates. For instance, while PLCs are described in the literature almost exclusively as a school-based initiative, in developing countries they often originate and are an integral part of education systems and-or education development programs.

We integrate our typology of PLCs and corresponding structural varying features with key elements proposed by the Western literature, forming one cohesive conceptual framework. The framework is organized around five interrelated PLC dimensions, three of which emerge from the Western literature (core characteristics, supportive conditions and phases of development) and two (PLC models and structural varying features) are based on a document review of PLCs in Sub-Saharan African countries and semi-structured interviews with practitioners, validated through discussion sessions with practitioners. Our purpose with this framework is to improve conceptual clarity around the multidimensional nature of PLCs and guide policy-makers and practitioners on the design and promotion of these collaborative structures.

This study considers the experience of a sample of Sub-Saharan African countries with a focus on primary education. In order to expand the validity of our typology into other settings, more research is needed that explore other regions of the world and other educational levels (e.g., secondary and tertiary). Nonetheless, we believe this study provides further insights into how PLCs currently function in developing countries and gives support to the development of PLC's conceptual foundations accounting for the reality in these countries. Finally, by proposing specific models according to which we can classify PLCs in a clear and consistent manner, we open the door for comparative analysis across different PLCs and different settings.

We acknowledge a few limitations of this study and of its final framework. First, the documents reviewed may not include all existing documents on PLCs in Sub-Saharan Africa. Local, regional or even national governments in Sub-Saharan Africa might have independently developed documents on PLCs without the support of international organizations that are not available online. Additionally, only four development organizations shared documents on PLCs with us. This may be because PLCs are a relatively new approach in the field of international education. Second, we adopted a convenience sample selection approach to the semi-structured interviews and validation sessions. Because we only included FHI 360 practitioners, we may be missing potentially different views and perspectives of experts working in other organizations. Finally, although we include the five core characteristics highlighted by the Western literature in 
our framework, there is a lack of studies investigating their relevance in low-resources contexts and even the empirical evidence-base in high-resources contexts is limited. Further research is warranted to investigate the extent to which these characteristics are reflective of the experience and functioning of PLCs in low- and middle-income countries.

Despite these limitations, the proposed integrated framework offers opportunity for future research to disentangle the relationships between the five dimensions and test empirically how these dimensions are inter-related. We need to better understand the role played by each dimension in promoting the five core characteristics in order to design strong PLCs. For instance, which of the three PLC models is most effective in promoting the five PLC core characteristics? And does this relationship between PLC model and core characteristics vary according to phases of development? Is it more beneficial to have scripted approaches when initiating a PLC versus an autonomous model for more mature, stronger, PLCs? The structural varying features may also play an important role in strengthening the five core characteristics. For example, does having a trained facilitator stimulate (or hinder) the development of any of the five core characteristics? The framework also allows for more research on which the PLC model can be most effective in producing different types of instructional change. The literature distinguishes between reformation versus transformation of practice (Lee et al., 2018; Philpott \& Oates, 2017; Servage, 2008). Reformation of practice involves aligning individual practices with prescribed norms or existing mandated goals (Philpott \& Oates, 2017). Transformation of practice involves questioning goals and empowering teachers to be "... producers of pedagogical knowledge rather than solely consumers and implementers" (Philpott \& Oates, 2017, p. 213). We need to further understand if scripted PLCs can effectively lead to transformation of practice or if they are more likely to work as vehicle for implementation of authority-endorsed change or mandates (Lee at al., 2018).

Finally, since PLCs are imbedded in a social, political, cultural and economic context, the typology opens the debate on which PLC model is best for different settings. In contexts characterized by high power distance, hierarchy and authoritarian education systems, which PLC model can more effectively facilitate changes in instructional practice? In such contexts, does the scripted model reinforce existing power dynamics or can it be helpful in moving towards real collaborative structures? Another question that arises is which PLC model is more suited for different levels of teacher capacity? When there is low teacher instructional capacity and/or low teacher ability to actively and reflectively construct knowledge about teaching and student 
learning, which PLC model can be more helpful in filling these gaps? There are still many questions to be answered around the optimal design and implementation of PLCs in different contexts. The new empirically based typology and integrated conceptual framework presented in this study provides a way to classify PLCs in a clear and consistent manner to facilitate future comparative analyses across different PLCs and different contexts. By building on this foundation, we can more efficiently and effectively realize the potential of PLCs to strengthen teachers' instructional practices and improve educational outcomes.

\section{References}

Abrahams, M. (1997). Collaborative space in South African schools: A comparative perspective. Journal of Negro Education, 66(4), 409-422.

Akyeampong, K., Lussier, K., Pryor, J., \& Westbrook, J. (2013). Improving teaching and learning of basic maths and reading in Africa: Does teacher preparation count? International Journal of Educational Development, 33(3), 272-282.

Altinyelken, H. K. (2010). Pedagogical renewal in sub-Saharan Africa: the case of Uganda. Comparative Education, 46(2), 151-171.

Atkinson, P. A. \& Coffey, A. (2004). Analyzing documentary realities. In D. Silverman (Ed.), Qualitative research: Theory, method and practice (2nd ed.), London: Sage, 56-75.

Atteberry, A., \& Bryk, A. S. (2011). Analyzing teacher engagement in literacy coaching activities.

Elementary School Journal, 112(2), 356-382.

Avalos, B. (1998). School-based teacher development the experience of teacher professional groups in secondary schools in Chile. Teaching and Teacher Education, 14(3), 257-271.

Bloor, M. (1997). Techniques of validation in qualitative research: a critical commentary. Context and method in qualitative research.

Bolam, R., McMahon, A., Stoll, L., Thomas, S., Wallace, M., Greenwood, A., ... \& Smith, M. (2005). Creating and sustaining effective professional learning communities. Bristol: University of Bristol y Departament of Education and Skills. 
A Typology of Professional Learning Communities (PLC) for Sub-Saharan Africa: A Case study of Equatorial Guinea, Ghana, and Nigeria

Bowen, G. A. (2009). Document analysis as a qualitative research method. Qualitative research journal, 9(2), 27-40.

Braun, V., \& Clarke, V. (2006). Using thematic analysis in psychology. Qualitative research in psychology, 3(2), 77-101.

Brodie, K. (2019) “Teacher agency in professional learning communities”, Professional Development in Education, DOI: 10.1080/19415257.2019.1689523

Bryk, A., Camburn, E., \& Louis, K. S. (1999). Professional community in Chicago elementary schools: Facilitating factors and organizational consequences. Educational administration quarterly, 35(5), 751-781.

Buysse, V., Sparkman, K. L., \& Wesley, P. W. (2003). Communities of practice: Connecting what we know with what we do. Exceptional children, 69(3), 263-277.

Carey, J. W., \& Gelaude, D. (2008). Systematic methods for collecting and analyzing multidisciplinary team-based qualitative data. Handbook for team-based qualitative research, 227-274.

Conje, F. and Bitzer, E.M. (2019), "Continuous Professional Learning in Private Higher Education: Making a Case for Distributed Leadership", South African Journal of Higher Education, 33(2), 52-68, DOI: http://dx.doi.org/10.20853/33-2-2808

Corbin, J., \& Strauss, A. (2008). Strategies for qualitative data analysis. Basics of Qualitative Research. Techniques and procedures for developing grounded theory, 3.

Council on Higher Education (2017), Learning to teach in Higher Education in South Africa, An investigation into the influence of institutional context on the professional learning of academics in their roles as teachers, Higher education monitor 14.

Du Plessis, J., \& Muzaffar, I. (2010). Professional Learning Communities in the Teachers' College: A Resource for Teacher Educators. EQUIP1.

DuFour, R. (2004). What is a" professional learning community"?. Educational leadership, 61(8), 6-11.

Englert, C. S., \& Tarrant, K. L. (1995). Creating collaborative cultures for educational change. Remedial and Special Education, 16(6), 325-336, 353. 
Feldman, Jennifer (2020), “The role of Professional Learning Communities to Support Teacher Development: A Social Practice Theory Perspective", South African Journal of Education, 40(1), DOI: https://doi.org/10.15700/saje.v40n1a1668

Fereday, J., \& Muir-Cochrane, E. (2006). Demonstrating rigor using thematic analysis: A hybrid approach of inductive and deductive coding and theme development. International journal of qualitative methods, 5(1), 80-92.

Fullan, M. G. (1991). The new meaning of educational change. New York, NY: Teacher College Press

Geijsel, F. P., Sleegers, P. J. C., Stoel, R. D., \& Krüger, M. L. (2009). The effect of teacher psychological and school organizational and leadership factors on teachers' professional learning in Dutch schools. Elementary School Journal, 109, 406 - 427.

Glaser, B. G. \& Strauss, A. L. (1967). The discovery of grounded theory: Strategies for qualitative research. Chicago: Aldine

Guest, G., MacQueen, K. M., \& Namey, E. E. (2012). Applied thematic analysis. Sage Publications.

Hargreaves, A., \& Fullan, M. G. (1992). Understanding teacher development. Teachers College Press, 1234 Amsterdam Avenue, New York, NY 10027.

Hipp, K. K., \& Huffman, J. B. (2003). Professional Learning Communities: Assessment-Development--Effects.

Hollins, E. R., McIntyre, L. R., DeBose, C., Hollins, K. S., \& Towner, A. (2004). Promoting a self-sustaining learning community: Investigating an internal model for teacher development. International journal of qualitative studies in education, 17(2), 247-264.

Hord, S. (1997). Professional learning communities: Communities of continuous inquiry and improvement. Austin, TX: Southwest Educational Development Laboratory

Huffman, J. B., \& Jacobson, A. L. (2003). Perceptions of professional learning communities. International Journal of Leadership in Education: Theory and Practice, 6(3), 239-250

Kruse, S. D., \& Louis, K. S. (1993). An Emerging Framework for Analyzing School-Based 
A Typology of Professional Learning Communities (PLC) for Sub-Saharan Africa: A Case study of Equatorial Guinea, Ghana, and Nigeria

Professional Community. Paper presented at the Annual Meeting of the American Educational Research Association (Atlanta, GA, April 12-16, 1993).

Kruse, S. D., \& Louis, K. S. (2007). Developing collective understanding over time: reflections on building professional community. Professional Learning Communities: Divergence, Depth and Dilemmas: Divergence, Depth and Dilemmas, 106.

Lee, J. C. K., Zhang, Z., \& Yin, H. (2011). A multilevel analysis of the impact of a professional learning community, faculty trust in colleagues and collective efficacy on teacher commitment to students. Teaching and teacher education, 27(5), 820-830.

Lee, D. H. L., \& Lee, W. O. (2018). Transformational change in instruction with professional learning communities? The influence of teacher cultural disposition in high power distance contexts. Journal of Educational Change, 19(4), 463-488.

Lincoln, Y. S. and Guba, E. G. (1985) Naturalistic Inquiry. Newbury Park, CA: SAGE.

Louis, K. S., \& Marks, H. M. (1998). Does professional community affect the classroom? Teachers' work and student experiences in restructuring schools. American Journal of Education, 107,532-575.

Lomos, C., Hofman, R. H., \& Bosker, R. J. (2011). Professional communities and student achievement-a meta-analysis. School effectiveness and school improvement, 22(2), 121148.

McLaughlin, M. W., \& Talbert, J. E. (2001). Professional communities and the work of high school teaching. Chicago: University of Chicago.

Mhakure, Duncan (2019), School-based Mathematics Teacher Professional Learning: A theoretical Position on the Lesson Study Approach, South African Journal of Education, vol 39(1), DOI: https://doi.org/10.15700/saje.v39ns1a1754

Mitchell, C., \& Sackney, L. (2000). Profound improvement: Building capacity for a learning community. Lisse, The Netherlands: Swets \& Zeitlinger.

Ndlovu, M. (2018), “Themes in Mathematics Teacher Professional Learning Research in South Africa: A Review of the Period 2006-2015”, In G. Kaiser et al (eds) (2018), Invited 
Lectures from the $13^{\text {th }}$ International Congress on Mathematical Education, ICME-13 Monographs, DOI: https://doi.org/10.1007/978-3-319-72170-5_22

Newmann, F. M. (1996). Authentic achievement: Restructuring schools for intellectual quality. Jossey-Bass.

Newmann, F. M. (2006). The meaning of staff-shared understanding and commitment. The keys to effective schools: Educational reform as continuous improvement, 33.

Nkambile, Thabisile and Tabitha Grace Mukeredzi (2017), Pre-serviceTeachers'professional learning experiences during rural teaching practice in Acronhoek, Mpumalanga Province, South African Journal of Education, vol 37(3), DOI: https://doi.org/10.15700/saje.v37n3a1371

Philpott, C., \& Oates, C. (2017). Professional learning communities as drivers of educational change: The case of learning rounds. Journal of educational change, 18(2), 209-234.

Piper, B., Destefano, J., Kinyanjui, E. M., \& Ong’ele, S. (2018). Scaling up successfully: Lessons from Kenya's Tusome national literacy program. Journal of Educational Change, 19(3), 293-321.

Pryor, J. (1998). Action research in West African schools: problems and prospects. International Journal of Educational Development, 18(3), 219-228.

Sackney, L., Walker, K., Mitchell, C., \& Duncan, R. (2005). Dimensions of school learning communities. Paper presented at the annual conference of the International Congress for School Effectiveness and School Improvement, Barcelona, Spain.

Servage, L. (2008). Critical and transformative practices in professional learning communities. Teacher education quarterly, 35(1), 63-77.

Sleegers, P., den Brok, P., Verbiest, E., Moolenaar, N. M., \& Daly, A. J. (2013). Toward conceptual clarity: A multidimensional, multilevel model of professional learning communities in Dutch elementary schools. The Elementary School Journal, 114(1), 118137.

Stoll, L., Bolam, R., McMahon, A., Wallace, M., \& Thomas, S. (2006). Professional learning communities: A review of the literature. Journal of educational change, 7(4), 221-258. 
A Typology of Professional Learning Communities (PLC) for Sub-Saharan Africa: A Case study of Equatorial Guinea, Ghana, and Nigeria

Stoll, L., \& Louis, K. S. (2007). Professional learning communities: Divergence, depth and dilemmas. McGraw-Hill Education (UK).

Strauss, A. \& Corbin, J. (1990). Basics of qualitative research: Grounded theory procedures and techniques. Newbury Park, CA: Sage.

Strauss, A. \& Corbin, J. (1998). Basics of qualitative research: Techniques and procedures for developing grounded theory (2nd ed.). London: Sage

Supovitz, J. A. (2002). Developing communities of instructional practice. Teachers College Record, 104(8), 1591-1626

Tatto, M. T. (1999). Improving teacher education in rural Mexico: The challenges and tensions of constructivist reform. Teaching and teacher education, 15(1), 15-35.

Toole, J., \& Louis, K. S. (2002). The role of professional learning communities in international education. In K. Leithwood \& P. Hallinger (Eds.), Second international handbook of educational leadership and administration (pp. 245-281). Dordrecht, The Netherlands: Kluwer.

Vescio, V., Ross, D., \& Adams, A. (2008). A review of research on the impact of professional learning communities on teaching practice and student learning. Teaching and teacher education, 24(1), 80-91.

Zhang, J., \& Pang, N. S. K. (2016). Exploring the characteristics of professional learning communities in China: A mixed-method study. The Asia-Pacific Education Researcher, 25(1), 11-21. 


\section{Appendix I: Essential characteristics-dimensions of Professional Learning Communities highlighted by the literature}

\begin{tabular}{|c|c|c|c|c|c|c|c|c|c|c|c|c|c|}
\hline & $\begin{array}{l}\text { Shared } \\
\text { values, } \\
\text { norms, } \\
\text { vision }\end{array}$ & $\begin{array}{l}\text { Focus on } \\
\text { student } \\
\text { learning - } \\
\text { Collective } \\
\text { responsibility }\end{array}$ & $\begin{array}{l}\text { Reflective } \\
\text { dialogue - } \\
\text { reflective } \\
\text { professional } \\
\text { inquiry }\end{array}$ & $\begin{array}{l}\text { Deprivatizing } \\
\text { practice - } \\
\text { shared } \\
\text { personal } \\
\text { practice }\end{array}$ & $\begin{array}{l}\text { Collaboration } \\
\text { - collective } \\
\text { learning and } \\
\text { application }\end{array}$ & $\begin{array}{l}\text { Normative } \\
\text { control }\end{array}$ & $\begin{array}{l}\text { Group, as } \\
\text { well as } \\
\text { individual, } \\
\text { learning is } \\
\text { promoted }\end{array}$ & $\begin{array}{l}\text { Mutual } \\
\text { trust }\end{array}$ & $\begin{array}{l}\text { Inclusive } \\
\text { membership }\end{array}$ & $\begin{array}{l}\text { Openness, } \\
\text { networks } \\
\text { and } \\
\text { partnerships }\end{array}$ & $\begin{array}{l}\text { Socialization } \\
\text { of new } \\
\text { professional } \\
\text { members }\end{array}$ & $\begin{array}{l}\text { Shared } \\
\text { and } \\
\text { supportive } \\
\text { leadership }\end{array}$ & $\begin{array}{l}\text { Physical } \\
\text { conditions } \\
\text { and Human } \\
\text { Capacities }\end{array}$ \\
\hline Kruise \& Louis (1993) & $x$ & $x$ & $x$ & $x$ & $x$ & & & & & & & & \\
\hline $\begin{array}{l}\text { Newmann et al. } \\
\text { (1996) }\end{array}$ & $x$ & $x$ & $x$ & $\mathrm{x}$ & $\mathrm{x}$ & & & & & & & & \\
\hline Hord (1997) & $x$ & & & $x$ & $x$ & & & & & & & $x$ & $x$ \\
\hline Bryk et al (1999) & & & $\mathrm{x}$ & $x$ & $x$ & $\mathrm{x}$ & & & & & $\mathrm{x}$ & & \\
\hline Bolam et al (2005) & $x$ & $x$ & $\mathrm{x}$ & & $\mathrm{x}$ & & $x$ & $x$ & $x$ & $x$ & & & \\
\hline Stoll et al. (2006) & $x$ & $x$ & $x$ & & $x$ & & $x$ & $x$ & $x$ & $x$ & & & \\
\hline
\end{tabular}


A Typology of Professional Learning Communities (PLC) for Sub-Saharan Africa: A Case study of Equatorial Guinea, Ghana, and Nigeria Appendix II. Document Analysis

\begin{tabular}{|c|c|c|}
\hline Country & Project/ Organization & Documents reviewed \\
\hline Democratic & Opportunities for Equitable & - White paper: Teacher Learning Circle Case Study: (Post)Crisis Katanga Province, DRC; IRC (2014). \\
\hline $\begin{array}{r}\text { Republic of } \\
\text { Congo }\end{array}$ & $\begin{array}{l}\text { Access to Quality Basic Education } \\
\text { (OPEQ) / International Rescue } \\
\text { Committee (IRC) }\end{array}$ & $\begin{array}{l}\text { - Frisoli, P. (2014). Teachers' experiences of professional development in (post)crisis Katanga province, Southeastern } \\
\text { Democratic Republic of Congo: A case study of teacher learning circles (dissertation), University of Massachusetts. } \\
\text { Final Report on the Impact of the OPEQ Intervention in the Democratic Republic of Congo. (draft) NYU and IRC, } \\
\text { (2016). }\end{array}$ \\
\hline $\begin{array}{r}\text { Democratic } \\
\text { Republic of } \\
\text { Congo }\end{array}$ & $\begin{array}{l}\text { Accelerating Access and Learning } \\
\text { in the DRC (ACCELERE!) Project / } \\
\text { Chemonics International }\end{array}$ & - $\quad$ The ACCELERE! Continuing Professional Development Program (FHI 360 program document). \\
\hline $\begin{array}{r}\text { Equatorial } \\
\text { Guinea }\end{array}$ & $\begin{array}{l}\text { Program for Educational } \\
\text { Development of Equatorial } \\
\text { Guinea (PRODEGE) / FHI } 360\end{array}$ & $\begin{array}{l}\text { - Teacher Learning Circle Guides for Areas 1-4, } 16 \text { guides (2018). } \\
\text { - Módulo de Formación Docente para la Acreditación Docente: Competencias de la docencia transformadora en } \\
\text { preescolar y primaria (Teacher's module for Diplomado in-service teacher training program.) (2018). } \\
\text { - ProFADs technical paper (paper that describes structure of PRODEGE teacher development programs) (2017). }\end{array}$ \\
\hline Ghana & $\begin{array}{l}\text { USAID Partnership for Education: } \\
\text { Learning / FHI } 360\end{array}$ & $\begin{array}{l}\text { - } \quad \text { USAID Partnership for Education: Learning: School-based INSET Guide (2017). } \\
\text { - } \quad \text { USAID Partnership for Education: Learning: Coaching/School-based INSET Resource Guide. (2017). } \\
\text { - } \quad \text { USAID Partnership for Education: Learning: Coaching/School-based INSET Facilitator Guide (2017). }\end{array}$ \\
\hline Nigeria & $\begin{array}{l}\text { Reading and Numeracy Activity } \\
\text { (RANA) / FHI } 360\end{array}$ & $\begin{array}{l}\text { - } \quad \text { Proposal for FHI 360's expanded scope of work in Nigeria, GEP 3/ EAC, UNICEF Nigeria (2017) } \\
\text { - } \quad \text { RANA Final Report (2018) } \\
\text { - } \quad \text { Meeting log form for RANA teachers }\end{array}$ \\
\hline Senegal & Passerelles / FHI 360 & - Facilitator Guide \\
\hline South Africa & $\begin{array}{l}\text { Department of Basic Education / } \\
\text { VVOB }\end{array}$ & $\begin{array}{l}\text { - Professional Learning Communities: A guideline for South African schools. (2015). } \\
\text { https://southafrica.vvob.be/sites/southafrica/files/professional learning communities a guideline for sout } \\
\text { h african schools } 0 \text { 0.pdf }\end{array}$ \\
\hline Tanzania & $\begin{array}{l}\text { WEKEZA project / International } \\
\text { Rescue Committee (IRC) }\end{array}$ & $\begin{array}{l}\text { - } \quad \text { Trainer's toolkit: Learning to Read in a Healing Classroom } \\
\text { - } \quad \text { Teacher Learning Circles (TLCS) Meeting Notes format } \\
\text { - } \quad \text { Organizing and Implementing Teacher Learning Circles: School-based toolkit }\end{array}$ \\
\hline Other & $\begin{array}{l}\text { International Network for } \\
\text { Education in Emergencies (INEE) }\end{array}$ & $\begin{array}{l}\text { - } \quad \text { The Facilitator's Guide } \\
\text { - } \quad \text { Peer Coaching Toolkit, Level } 1 \text { - TLCs only } \\
\text { - } \quad \text { Peer Coaching Toolkit, Level } 2 \text { - TLCs plus classroom observations } \\
\text { https://inee.org/resources/teachers-crisis-contexts-peer-coaching-pack }\end{array}$ \\
\hline
\end{tabular}

